WP 17-01

\title{
When Income Depends on Performance and Luck: The Effects of Culture and Information on Giving
}

Pedro Rey-Biel

Universitat Autònoma de Barcelona and Barcelona GS

Roman M. Sheremeta

Weatherhead School of Management

Case Western Reserve University

Neslihan Uler

Department of Agricultural and Resource Economics

University of Maryland

Copyright (C) 2017 by Pedro Rey-Biel, Roman M. Sheremeta and Neslihan Uler

All rights reserved. Readers may make verbatim copies of this document for non-commercial purposes by any means, provided that this copyright notice appears on all such copies. 


\title{
When Income Depends on Performance and Luck: The Effects of Culture and Information on Giving
}

\author{
Pedro Rey-Biel ${ }^{\text {a }}$ \\ Roman Sheremeta ${ }^{\text {b,* }}$ \\ Neslihan Uler ${ }^{\mathrm{c}}$ \\ ${ }^{a}$ Universitat Autònoma de Barcelona and Barcelona GSE \\ ${ }^{\mathrm{b}}$ Weatherhead School of Management at Case Western Reserve University \\ and the Economic Science Institute at Chapman University \\ ${ }^{\mathrm{c}}$ University of Maryland
}

January 18, 2017

\begin{abstract}
We study how giving depends on income and luck, and how culture and information about the determinants of others' income affect this relationship. Our data come from an experiment conducted in two countries, the US and Spain, that have different beliefs about how income inequality arises. We find that when individuals are informed about the determinants of income, there are no crosscultural differences in giving. However, when uninformed, Americans give less than the Spanish, and this difference persists even after controlling for beliefs, personal characteristics, and values.
\end{abstract}

JEL Classifications: C91, D64, D83

Keywords: individual giving, information, culture, beliefs, laboratory experiment

* Corresponding author: Roman Sheremeta, Email: rms246@case.edu, Phone: (216) 368-4271. An older version of this paper has been circulated under the title “(Bad) Luck or (Lack of) Effort? Comparing Social Sharing Norms between US and Europe.” We thank Miguel Ballester, Yan Chen, Rachel Croson, Lata Gangadharan, Gianluca Grimalda, Jim Hines, Juyeon Ha, Chris House, Silvana Krasteva, Michal Krawczyk, James Konow, Maciej Kos, Erin Krupka, Yusufcan Masatlioglu, Louis Putterman, Ernesto Reuben, Joel Slemrod, Erik Sorensen, Jeff Smith, and seminar participants at the University of Michigan, University of Texas Dallas, and participants at the International Economic Science Association Conference in Chicago, Political Economy of Conflict Conference in Berlin, 4th ACCER Workshop in Duisburg, and the 2014 Science of Philanthropy Initiative Annual Conference. Pedro Rey-Biel acknowledges financial support from Ministerio de Economía y Competición (ECO2012-31962). Neslihan Uler thanks Russell Sage Foundation for financial support. Roman Sheremeta thanks Economic Science Institute and Chapman University for financial support. Any remaining errors are ours. 


\section{Introduction}

European governments are significantly more redistributive than the US government with more progressive tax systems and more generous social programs (Alesina et al., 2001; Alesina and Glaeser, 2004). ${ }^{1}$ While Americans have higher charitable giving than other countries, redistribution from the rich to the poor is much more extensive in Europe than in the US, even after accounting for significant differences in charitable giving. ${ }^{2}$ For example, EU countries on average have about twice as much governmental spending on individual consumption (health care, housing, education, etc.) than the US.

Alesina and Glaeser (2004) argue that comparing only the welfare states would not be enough to conclude that Europeans are more altruistic. ${ }^{3}$ An important piece of the explanation as to why different cultures have different giving norms may rely on beliefs about how income inequality arises (Alesina et al., 2001; Benabou and Tirole, 2006; Fernández, 2010). Those who believe economic outcomes mainly depend on individual effort may oppose redistribution towards poor individuals, since they believe that poverty is most likely due to laziness. On the other hand, those who believe that other factors not under an individual's control (such as luck) determine economic outcomes may be more in favor of redistribution to the poor.

To examine how individuals condition their giving on income and luck, and how culture affects this relationship, we conduct a controlled laboratory experiment in the US and Spain. According to the World Values Survey (1995), 68\% of respondents in Spain said "poverty is due to unfair society” while only $16 \%$ said "poverty is due to laziness and lack of willpower." These

\footnotetext{
${ }^{1}$ According to the OECD Better Life Index (2013), average governmental spending for EU countries was almost 13 percent, whereas American spending was about 6 percent.

${ }^{2}$ According to the World Giving Index (2014), the US is the most charitable country in the world with the charitable sector being approximately 2 percent of GDP. However, even after controlling for charitable giving, redistribution is higher in Europe.

${ }^{3}$ For example, Americans could derive higher utility from giving, or they may have a preference for being able to choose where to spend their money instead of paying larger taxes.
} 
results place Spain on the other side of the spectrum with respect to the US, where these percentages are $30 \%$ and $48 \%$, respectively. Therefore, higher redistributive norms in Spain compared to the US could be the result of differences in beliefs about how income inequality arises (Alesina and Angeletos, 2005). To test this hypothesis, we examine how giving differs across cultures when individuals are uninformed about the determinants of others' income. As opposed to naturally occurring data, our controlled environment shuts down the possibility of differences in government redistribution policies (Alesina and Glaeser, 2004). Hence, our experiment is able to isolate the innate differences across cultures in preferences for giving, if any, and how these preferences are impacted by beliefs about how income inequality arises.

To our knowledge, our paper offers the first cross-cultural comparison in giving between two countries with opposing beliefs about the determinants of income by using an experiment in which beliefs about such determinants are elicited in an incentive compatible manner. Moreover, in addition to the cross-cultural aspect, our study provides a novel design and allows us to answer other interesting questions that previous studies could not. In particular, we are able to investigate the determinants of giving and beliefs for each culture and study whether giving depends on information about how others' income is generated.

In our experiment, income is determined by individual performance and luck. In most experimental studies, income is either randomly determined by the experimenter or it depends solely on individual performance (Konow, 2000; Andreoni, 2006; Vesterlund, 2006). In contrast, in our experiment, income is determined by a combination of performance on a real-effort task (counting the number of certain specific letters in a fixed number of sequences) and luck (a random shock) which creates a more realistic setting and allows us to study whether there are any interaction effects of luck and performance on giving. More importantly, we vary the information 
presented to individuals at the time of giving (i.e., whether individuals could observe how others' income was determined or not). This allows us to study how individuals react to such information (or lack of it). Finally, in cases where individuals do not observe the determinants of income, we elicit individual beliefs about how the income of others is generated.

Before summarizing our findings, we want to emphasize that even though our study was conducted at two select universities in the US and Spain, the survey that we conducted after the experiment replicates the important patterns reported in the World Values Survey regarding the beliefs about the determinants of income, government responsibilities and religion, strengthening the validity of our experimental results.

Coming back to our results, we find that both culture and information affect individual giving. Our results indicate that while the overall amount of giving is similar between the two countries when participants are informed about the determinants of others' income, there exist important cross-cultural differences when individuals are uninformed, with Americans giving significantly less than Spanish participants. Moreover, the cross-cultural difference in giving persists even after controlling for the beliefs, personal characteristics, and values.

In Section 2 we summarize the related papers. We describe the experimental design and procedures in Section 3, and present our main results in Section 4. The implications of our results are discussed in Section 5.

\section{Related literature}

Alesina and Angeletos (2005) provide a theoretical model suggesting that Europe has higher redistribution policies than the US because Europeans believe that luck and connections have strong effects on wealth, whereas Americans believe that personal effort determines wealth. 
This study raises an important question. Can differing beliefs be an explanation for observed crosscultural differences as suggested by Alesina and Angeletos (2005)?

There is a large literature on the relationship between how income is generated and individual giving decisions. Many economic experiments study how individuals give when all determinants of income are known (Andreoni, 2006; Vesterlund, 2006). ${ }^{4}$ Hoffman et al. (1994), for example, show that in the dictator game, agents give less when they earn their right to be the dictator. Similarly, Cherry et al. (2002) and Oxoby and Spraggon (2008) show that dictators give (take) less when income is earned by the dictators (recipients) compared to when income is determined by the experimenter. Konow (2000), Cappelen et al. (2007), Konow et al. (2009), Erkal et al. (2011), Lefgren et al. (2016) and Tonin and Vlassopoulos (2017) study different fairness principles when all determinants of income, such as effort and luck, are known. There are three exceptions: Fong $(2001,2007)$ investigates the impact of beliefs on redistributive preferences. Ubeda (2014) uses a similar experimental set-up to our no information treatment to compare the consistency of different fairness rules. Caballero (2016) studies the impact of information about opportunities on redistributive behavior. However, none of these papers are cross-cultural and none elicit beliefs about the determinants of income.

Cross-cultural experiments have been used to understand giving norms across cultures when determinants of income are known (Roth et al., 1991; Anderson et al., 2000; Henrich et al., 2001; Cason et al., 2002; Guiso et al., 2006; Herrman et al., 2008; Jakiela, 2015). In addition, the US and Spain have been the focus of other cross-cultural experimental studies. Brandts et al. (2004), for example, find no significant differences in contributions to public goods between the

\footnotetext{
${ }^{4}$ Most of the experimental studies involve a small number of participants interacting with each other. However, the demand for redistribution in the context of taxation with large groups has also been investigated (Ackert et al., 2007; Krawczyk, 2010; Farina and Grimalda, 2011; Esarey et al., 2012; Durante et al., 2014; Sheremeta and Uler, 2016).
} 
US and Spain, while Alm et al. (1995) and Alm and Torgler (2006) find higher tax compliance in the US compared to Spain. In the context of cross-cultural studies, the most related paper to ours is by Farina and Grimalda (2011), who study preferences for redistribution in the US, Italy and Norway. However, their focus is on taxes in a redistributive environment whereas we are interested in individual giving in order to control for altruistic preferences without strategic interactions among subjects. Moreover, the novelty of our study is that we examine the beliefs about the determinants of income and also control for them while investigating the cross-cultural differences in giving norms.

In summary, while there is a large literature on understanding sharing norms and how culture affects giving, there has not been any study that systematically compares sharing norms across cultures where income is determined by both performance and luck, and where information and beliefs regarding determinants of income are controlled for. While many studies argue that the observed cultural differences are due to differing beliefs, our paper demonstrates that even after controlling for beliefs, cross-cultural differences still exist.

\section{Experimental design and procedures}

We conducted sixteen experimental sessions at Universitat Pompeu Fabra in Barcelona, Spain and University of Michigan, USA. ${ }^{5}$ A total of 280 individuals participated in the study. The computerized experimental sessions used z-Tree experimental software (Fischbacher, 2007). Participants were given the instructions (available in Appendix A) at the beginning of the session

\footnotetext{
${ }^{5}$ Both universities share similar aspects: they are both one of the largest universities in their countries, and they are both public schools.
} 
and the experimenter read the instructions aloud. ${ }^{6}$ At the end of the experiment, participants were paid in private and in cash.

Experiments were double-blind. Nobody, not even the experimenter, knew how much each participant earned from the experiment. Participants earned approximately $\$ 20$ (15€) on average, and sessions (including the instruction time) lasted approximately 70 minutes. Instructions were written in English and then translated into Spanish. Two independent assistants translated the instructions back to English to check for any inconsistencies.

In our experiment, participants earn income based on performance and luck. ${ }^{7}$ In the first stage of the experiment (the earning stage) all participants had 30 minutes to count the sum of "a" and "d" characters contained in a series of 50-character sequences which were presented to all participants in the same order. This information was made common knowledge such that differences in outcomes could not be attributed to possible differences in the difficulty of the task. ${ }^{8}$ Characters included letters, punctuation marks, numbers, and symbols. Each participant worked on the task independently. Participants were told that their earnings (total income) was determined by the sum of the number of correct counts (individual income from performance) and a random shock (individual income from luck) drawn from a discrete uniform distribution which could take values $-50,-25,0,+25$, or $+50 .{ }^{9}$ Participants were also told that they could stop counting characters

\footnotetext{
${ }^{6}$ Two coauthors of this paper ran the initial sessions together to agree on the same experimental procedures and then followed it independently for the rest of the experiments.

${ }^{7}$ While most papers in the literature do not have this property, there are some studies in which income is determined by both performance and luck (i.e., Cappelen et al., 2007; Erkal et al., 2011; Rubin and Sheremeta, 2016).

${ }^{8}$ There were 300 sequences, which is more than anyone could finish within the allocated time. The task is inspired by the data entry task of Gneezy and List (2006). Our task is also similar to Abeler et al. (2011), where participants had to count the number of zeros in tables that consist of 150 randomly ordered zeros and ones. Such tasks are mainly effort-related and not skill-related, i.e., success in such a task is mainly attributed to hard work more than to individual skill.

${ }^{9}$ We used a piece rate scheme and a task not depending on cultural differences and/or skill in order to control for preferences for competition across different cultures and to minimize the role of skill/knowledge on earnings. Some experiments employ tournaments to determine earnings, or rely on skill or knowledge related tasks (Erkal et al., 2011; Cherry et al., 2002). In case the random shock was negative and the number of correct counts was less than the absolute value of the random shock, the computer set earnings for the first part to zero.
} 
or take a break whenever they wanted, and in fact, newspapers were left on each participants' desk to reduce stigma on shirking.

In the second stage of the experiment, the giving stage, participants were matched in pairs and each participant had an opportunity to give part of his/her income to another participant (a two-player dictator game). Each participant received the information about their own income, their own number of correct counts and their own random shock. In the INFO treatment, participants also received the same information about their matched participant, while in the NOINFO treatment, participants were only told about the total income of their matched participant (i.e., the sum of the random shock and number of correct counts). For each pair, the computer randomly determined which of the two decisions would count to determine payments. ${ }^{10}$ We followed a between-subjects design.

Finally, the NOINFO treatment contained a (surprise) third stage, which was not present in the INFO treatment. In this third stage, we used incentivized elicitation of participants' beliefs about the other participant's random shock, rewarding an exact correct guess with 10 tokens.

At the end of the experiment, and while participants waited to be paid, they filled out a questionnaire (available in Appendix B), eliciting self-reported measures about perceptions, personal characteristics and values. At the end of the experiments, participants' earnings were converted to US Dollars or Euros at a conversion rate of 1 token $=\$ 0.15$ or 1 token $=0.1 €$, which was very close to the currency exchange rate at the time. In the following, all results will be reported in tokens.

\footnotetext{
${ }^{10}$ Iriberri and Rey-Biel (2011) show that in modified dictator games, individuals give more when the role of dictator is fixed rather than uncertain. Brandts and Charness (2011) survey the methodological literature on the strategic methods and point out their validity. In any case, the cross-country comparison should not be affected.
} 


\section{Results}

\subsection{Individual giving}

Before examining individual giving, it is important to emphasize that based on the Wilcoxon rank-sum test we do not find any significant differences in performance between participants in Spain and the US (82.2 versus 79.1, p-value $=0.14) .{ }^{11}$ Therefore, any difference in giving between the two countries cannot be attributed to aggregate differences in performance or income (since income is generated based on performance). Looking at the level of individual giving, we observe relatively lower average giving (an average of 3\% of income) and lower proportion of positive giving (an average of $29 \%$ of all giving) than in most previous experimental studies (Camerer, 2003). This may be partially due to our double blind experimental procedure and partially due to entitlements of earned income (Hoffman et al., 1994; Cherry et al., 2002).

Figure 1 shows the average giving by treatment and country. ${ }^{12}$ Using the Wilcoxon ranksum test, we find no significant cross-cultural differences in giving in the INFO treatment (1.9 in Spain versus 2.4 in US, p-value $=0.57$ ). Moving from the INFO to NOINFO treatment, we find that Spanish participants increase their average giving from 1.9 to $4.4(\mathrm{p}$-value $=0.21)$, while Americans decrease their giving from 2.4 to 1.3 (p-value $=0.16$ ).${ }^{13}$ As a result, in the NOINFO treatment, the average giving in Spain is higher than in the USA and the difference is statistically significant based on the two-tailed Wilcoxon rank-sum test $(4.4$ versus 1.3 , p-value $=0.04)$.

\footnotetext{
${ }^{11}$ All reported results use two-tailed tests.

${ }^{12}$ Results reported in the paper do not include the three outliers who gave all their earnings. Including or excluding them only affect the averages but do not affect the qualitative results of the paper. Results without eliminating the outliers can be requested from the authors.

${ }^{13}$ We also ran Tobit regressions to test the effect of information by controlling for the participant's own income from performance, own income from shock and the paired participant's net income. We cannot reject the hypothesis that Spanish do not change their giving between INFO and NOINFO ( $\mathrm{p}$-value $=0.14$ ) but Americans significantly decrease their giving when uninformed ( $\mathrm{p}$-value $=0.05)$.
} 
Although nonparametric tests give us insights about giving decisions across treatments and countries, they are not entirely informative since they do not control for important variables, such as individual performance, luck, and beliefs. We thus turn to regression analysis to control for these relevant factors in giving decisions. Since we have censored data, OLS regressions would give inconsistent estimates. Therefore, we report Tobit regressions in the main text. However, our results are also robust to running OLS estimations as can be seen in Appendix C.

Table 1 reports Tobit regressions with robust standard errors, where the dependent variable in all regressions is giving. ${ }^{14}$ Independent variables in regressions (1)-(3) are individuals’ income from performance (own-income and other-income), individuals’ income from random shock (ownluck and other-luck), and a dummy variable for USA sessions (usa). Regression (3) in Table 1 shows that controlling for own-income, other-income, own-luck and other-luck, the usa dummy is not statistically significant in the INFO treatment. The same conclusion stands when using OLS regressions (see Table C1).

In the NOINFO treatment, participants were not informed about the other participant's income from performance or random shock, but only the other participant's total income. Therefore, instead of using other-income and other-luck variables, we use other-total-income as a dependent variable in regressions (4)-(7). Regression (6) shows that the usa dummy is statistically significant at the 5\% level when participants are uninformed. Regression (7) also controls for individual's belief regarding the random number of the paired participant (belief). The variable

\footnotetext{
${ }^{14}$ We choose to report Tobit regression analysis in the main text since the majority of giving in the INFO and NOINFO is 0 . We also included giving of 1 token as evidence of censoring, since such gifts have no significant monetary bearing ( 1 token $=\$ 0.15$ ). If we do not include giving of 1 token as evidence of censoring, none of the major qualitative results (such as the cross-cultural difference in giving) change. The estimation results are available from the authors upon request.
} 
belief takes values -50, -25, 0, 25 and 50. Even after controlling for beliefs, cross-cultural differences in giving still exist. The main finding of the paper is presented in Result 1.

Result 1: When individuals are informed about the determinants of income, there are no cross-cultural differences in giving. However, when uninformed, Americans give less than Spanish.

Could the difference in the average giving between Spanish and Americans in the NOINFO treatment be explained by the differences in the number of givers? To answer this question, Figure 2 provides a comparison of giving distributions by treatment and country. Using the two-sample test of proportions, we find that in the INFO treatment, the proportion of positive giving in Spain is not different than in the US (28\% versus $32 \%$, p-value $=0.63$ ). Similarly, we find no difference in the NOINFO treatment at the $95 \%$ confidence level $(34 \%$ versus $22 \%$, p-value $=0.10)$. In addition, a Logit regression which controls for the observable variables (as in Table 1) shows that the probability of giving in Spain is not significantly different from the probability of giving in the US, both in the INFO treatment ( $\mathrm{p}$-value $=0.71)$ and in the NOINFO treatment $(\mathrm{p}$-value $=0.16) .{ }^{15}$ Therefore, the difference in the average giving between Spanish and Americans in the NOINFO treatment cannot be explained by the differences in the number of givers.

\subsection{The determinants of giving}

Table 1 also provides information regarding the determinants of giving. Regression (1) indicates that in the INFO treatment, Spanish participants condition their giving on own-luck and other-income, with giving increasing in own luck and decreasing in the other's income. Previous studies on two-person dictator games (e.g., Hoffman et al., 1994; Cherry et al., 2002; Cappelen et

\footnotetext{
${ }^{15}$ The estimation results are available from the authors upon request.
} 
al., 2007) suggest that individuals are more generous when their wealth depends solely on a random shock, which would explain why participants who receive a positive shock increase their giving. Also, it is intuitive that participants observing higher other-income may conclude that such participants do not need additional income. ${ }^{16}$ Regression (2) shows that Americans, similar to Spanish participants, condition their giving on own-luck and other-income. We also find that Americans condition their giving on own-income, with giving increasing in own income. When we pool the data from both countries, as in regression (3), we find that own-luck and other-income significantly impact giving. We also see that own-income effects giving but it is only marginally significant.

Next, we examine the determinants of giving in the NOINFO treatment. Regression (4) indicates that when uninformed Spanish participants condition their giving solely on own-luck, with giving increasing in the own luck. Regression (5) indicates that American participants condition their giving on own-income, with giving increasing in own income. We find that neither Americans nor Spanish condition their giving on other-total-income in the NOINFO treatment. Regression (6) shows that other-total-income has a marginally significant effect on giving, but regression (7) shows that the effect disappears once beliefs are controlled for. Note that regression (7) shows that individuals do not condition their giving on their belief regarding the other participants' random draw, which might be surprising. However, this is consistent with the observation that individuals condition their giving on own-luck, but do not condition their giving on other-luck in the INFO treatment. We provide a more in depth analysis of beliefs in Section 4.3. Result 2 summarizes the determinants of giving for each culture and information condition. ${ }^{17}$

\footnotetext{
${ }^{16}$ Perhaps individuals with low performance in the real-effort task receive higher transfers, partly because they generate low income and partly because they are perceived as low skilled.

${ }^{17}$ Given that in our experiment, subjects only make one decision, we do not have enough statistical power to study whether the determinants of giving (i.e., coefficients of covariates) are actually statistically significantly different
} 
Result 2: When informed about how others’ income is generated, both Americans and Spanish increase their giving in own luck and decrease in the other's income. Americans also condition their giving on own-income. When uninformed about how others' income is generated, Spanish increase their giving in own-luck, while Americans increase their giving in own-income.

\subsection{Beliefs about luck}

While our initial analysis in Table 1 shows that beliefs do not account for the differences we observe in giving across cultures, this section gives a more detailed analysis, confirming our initial result.

Recall that the variable belief takes values $-50,-25,0,25$ and 50 . Since belief is a categorical and ordered variable, we use ordered logistic regressions to study the determinants of beliefs. Table 2 reports the estimation results (OLS regressions are in Table C2 in Appendix C). Not surprisingly, both in Spain (regression 1) and in the US (regression 2), we find strong positive correlation between belief and other-total-income. This indicates that when participants observe higher performance by others, they tend to believe that such performance was significantly influenced by luck. Interestingly, beliefs are also significantly correlated with own-income. Participants with lower income (coming from lower performance) guess higher numbers. Regression (3) shows that in our controlled study there are no cross-cultural differences in forming beliefs regarding the random number.

across cultures and information conditions. The earlier version of this manuscript included pooled regressions with the interaction terms. We found that most of the interactions were not significant, and that Tobit and OLS regressions did not always agree. Since the results are not robust and the possibility of making a Type II error is large, we choose to remain agnostic regarding whether there are significant cross-cultural differences in terms of the determinants of giving and whether information significantly changes the determinants of giving. 
Regressions (4)-(6) use a slightly different belief variable. Now the dependent variable belief has two categories: luck plays a positive role in generating income $($ belief $=1)$ or not (belief $=0$ ). Similarly, we find a negative relationship between belief and own-income as well as a strong positive correlation between belief and other-total-income. Again, there are no cross-cultural differences in forming beliefs regarding the random number.

Result 3: When forming beliefs about how the income of others is generated, both Spanish and American participants increase their beliefs when other-total-income increases and decrease their beliefs when own-income increases.

While we do not find any significant differences in beliefs across cultures, we provide a stronger test to see whether beliefs can explain observed differences in giving between Americans and Spanish participants in the NOINFO treatment if we allow for the belief variable to interact with other independent variables in a more flexible manner. Table 3 reports estimation results for Tobit regressions (OLS regressions are in Table C3 in Appendix C). For convenience, regression (1) in Table 3 is the same as regression (7) in Table 1. Recall that we found in the NOINFO treatment that Americans give significantly less than Spanish, which is indicated by a significant dummy usa. The only difference in regression (2) is that we add interaction terms with belief, where belief takes values -50, -25, 0, 25 and 50. Regressions (3) and (4) use the variable belief, where belief takes values 0 or 1 . Table 3 shows that in all regressions the usa dummy is negative and significant at the $5 \%$ level.

Result 4: Difference in giving levels between American and Spanish individuals who are uninformed about the determinants of income persists even after controlling for their beliefs.

In summary, we do not observe any significant differences across cultures in forming beliefs regarding the random number. This demonstrates that our participants are similar in terms 
of how they perform Bayesian updating. ${ }^{18}$ Nevertheless, we still observe differences in giving across cultures. We conjecture that even when beliefs do not differ substantially, low information environments impose different giving norms across cultures. ${ }^{19}$

\subsection{Personal characteristics and values}

This section provides additional robustness checks for our results by pooling all the data and controlling for personal characteristics and values. Table 4 shows the summary of personal characteristics by country. ${ }^{20}$ First, we asked participants to report how hard they think they had worked on the real-effort task in our experiment, using a scale from 1 to 10 . Participants also reported their gender, age, birthplace, income, and what proportion of that income comes from their own work, as well as their personal values regarding issues such as family, religion, leisure, work, their political orientation (politics), and their attitude towards government responsibilities.

The variables family, religion, and leisure take values from 1 to 6 where 1 corresponds to “extremely important” and 6 corresponds to "not important at all.” The variable work takes values from 1 to 7 , where 1 corresponds to the participant thinking 'Less importance placed on work in our lives' is "extremely desirable” and 7 corresponds to the participant thinking the same change is “extremely undesirable.” The variable politics takes values from 1 to 7 , where 1 corresponds to “extreme left” and 7 corresponds to "extreme right.” The variable government takes values from 1 to 7 where 1 corresponds to the participant completely agreeing that government should take

\footnotetext{
${ }^{18}$ Note that this does not mean that there are no cultural differences in beliefs in a more general setting. In fact, in Section 4.4, we show that American participants and European participants answered a question on "what determines income inequality" quite differently from each other.

${ }^{19}$ It may still be true that some part of the explanation as to why redistributive systems between the US and Europe is due to differing beliefs. Nevertheless, in a controlled environment such as ours, we show that participants in both cultures have similar beliefs, yet they still give differently.

${ }^{20}$ Questionnaire data from session 8 of our experiment was lost due to a problem with the server. Thus, we only include data from the remaining sessions.
} 
more responsibility to ensure that everyone is provided for, and 7 corresponds to the participant completely disagreeing with this statement. Finally, participants were asked whether they think that hard work brings success or whether success is a matter of luck and connections. The variable luck takes values from 1 to 7 , where 1 corresponds to the participant completing agreeing with that statement and 7 corresponds to the participant completely disagreeing. ${ }^{21}$

Table 4 shows that although gender and age composition of our participant pools are similar, there are several important differences across cultures. First, we see that Americans report higher numbers than Spanish when they are asked about how hard they think they had worked on the real-effort task in our experiment, even though the number of correct counts is very similar across the two countries. ${ }^{22}$ Second, Americans have higher income, higher family values and put more importance on religion. Spanish participants are more likely to believe that "hard work doesn't bring success" and that "the government should take more responsibility to ensure everyone is provided for” and stated that they are more left-oriented in politics. ${ }^{23}$

While our study was conducted at only one university per location, one can contrast the survey results from our experiment with the World Values Survey to check for how representative our samples are. We have investigated the World Values Survey 2005-2009 and 2010-2014 waves. We find that the results from the survey in our experiment are consistent with the patterns reported

\footnotetext{
${ }^{21}$ While we have also elicited birthplace, we later figured that this variable was not exactly serving our purposes well. For example, instead of birthplace, a measure for where a participant was raised would be a better measure for cultural proxy.

${ }^{22}$ We check whether averages may be misleading by studying the distribution of answers for this question. We see striking differences. Among the Spanish participants, only 1 reported a 9 and none reported a 10 in this question. Meanwhile, over $40 \%$ of Americans reported either a 9 or a 10. In addition, when we regress correct counts on the level of how hard a participant reported to work, there is a strong positive relationship for Americans (p-value $<0.01)$ but not for Spanish ( $\mathrm{p}$-value $=0.67)$. One explanation is that Americans put a higher value on being perceived as hardworking individuals compared to Spanish.

${ }^{23}$ Americans also report that they put more importance on leisure time and Spanish agreed more with the statement "less importance should be placed on work in our lives." However, these differences are only significant at the 10 percent level.
} 
in the World Values Survey for the variables luck, religion, and government, suggesting that our sample of participants is representative of general population along these dimensions. ${ }^{24}$

Result 5: The survey responses by American and Spanish participants of our experiment replicate the patterns reported in the World Values Survey regarding the attitudes towards beliefs about the determinants of income, government responsibility and religion.

Next, we run a robustness check by controlling for personal characteristics and values. Given a relatively small number of observations, we need to pool the data from all treatments. We begin by estimating a simple Tobit regression where giving is the dependent variable, and the independent variables are usa dummy, noinfo dummy, and usa×noinfo interaction. Table 5 reports estimation results for Tobit regressions (OLS regressions are in Table C5 in Appendix C). Consistent with our previous non-parametric analysis, regression (1) shows sizable and significant interaction between usa and noinfo, suggesting that Americans give less than Spanish in the NOINFO treatment. Regression (2) adds relevant experimental control variables, regression (3) adds demographics, and regression (4) drops foreigners. These regressions show that even after controlling for personal characteristics and values, the interaction effect is still negative and significant at the $5 \%$ level.

Result 6: Cross-cultural difference in giving between Americans and Spanish individuals who are uninformed about the determinants of income persists even after controlling for personal characteristics and values.

\footnotetext{
${ }^{24}$ The variable family does not generate consistent predictions across these two waves. World Values Survey 20052009 is consistent with the result "Americans have higher family values" but 2010-2014 finds an opposite result, although the difference is very little.
} 


\section{Discussion}

Despite abundant research on the subject, why Europeans redistribute more than Americans is largely unknown. To address this issue we designed a novel experiment to study how individuals condition their giving on income and luck, and how culture and information affect this relationship. We conducted our experiments in two countries, the US and Spain, that have different beliefs about how income inequality arises. We find that both culture and information affect individual giving. Giving is similar across cultures when individuals are informed about how others' income is generated. However, when individuals are uninformed, Americans give less while Spanish give more. Moreover, the cross-cultural difference in giving persists even after controlling for the beliefs, personal characteristics, and values.

Of course, our results on cross-cultural differences in giving should be taken with caution since we have only one location from each country. It is possible that location and geography can also play a role. However, our main point is still valid. Our study uses two very different participant pools, whose responses are consistent with the findings of the World Values Survey. Moreover, our treatment manipulations target the question of how these two different populations change their giving behavior in response to information about how income of others is generated.

Our study contributes to several areas of research. First, our study contributes to the discussion about different fairness ideals such as strict egalitarianism, libertarianism, and liberal egalitarianism (Konow, 2000; Cappelen et al., 2007). While strict egalitarians consider equal sharing a fair distribution, libertarians oppose redistribution and liberal egalitarians believe individuals should not be held responsible for circumstances beyond their control. As in Cappelen et al. (2007, 2013), in a two-person dictator game, we find some evidence for liberal egalitarianism both for Spanish and American participants, since when informed about the determinants of others' 
income, they conditioned their giving on own-luck (see Table 1 ). ${ }^{25}$ Our results are thus linked to Konow's accountability principle (Konow, 1996; Konow, 2000), which states that rewards should be allocated in proportion to the relevant variables that an individual can influence (i.e., earning income from performance) but not according to those that he cannot influence (i.e., earning income from luck).

Our study also sheds light on why previous studies do not always agree on what is the relationship between the level of income and giving: Eckel et al. (2007) and Smeets et al. (2015) find a positive relationship; Auten et al. (2000), Erkal et al. (2011) and Tonin and Vlassopoulos (2017) find nonlinear relationship between income and individual giving; Andreoni and Vesterlund (2001) and Buckley and Croson (2006) find no significant relationship at all. In particular, the results of our experiment suggest that the uncertainty about how income is generated and cultural differences affect the relationship between income and giving. Therefore, our paper suggests that findings from studies on generosity that took place in Europe may not always be consistent with findings from studies in the US and vice versa. This highlights the importance of replication in order to see how much of the findings presented in this and other studies could be generalized.

There are important policy implications of our study. For example, one implication is for charitable organizations in the US. Our paper suggests that Americans do not have different tastes in terms of the level of giving when individuals are informed about the causes of poverty, but they give less compared to Europeans when they are uninformed. This would also be consistent with why Americans like to direct a big portion of their giving to underdeveloped nations where it is

\footnotetext{
${ }^{25}$ Cappelen et al. (2007) conducted their experiment in Norway, while Cappelen et al. (2013) conducted their webbased experiment in Norway, Germany, Uganda and Tanzania.
} 
obvious that poverty is caused by circumstances beyond individual control. Charitable organizations could benefit from providing more information to their potential donors. 


\section{References}

Abeler, J., Falk, A., Goette, L., \& Huffman, D. (2011). Reference points and effort provision. American Economic Review, 101, 470-492.

Alesina, A., \& Angeletos, G.M. (2005). Fairness and redistribution. American Economic Review, 95, 960-980.

Alesina, A., \& Glaeser, E.L. (2004). Fighting poverty in the US and Europe: A world of difference. Oxford: Oxford University Press.

Alesina, A., Glaeser, E., \& Sacerdote, B. (2001). Why doesn't the US have a European-style welfare system? Brookings Papers on Economic Activity, 2, 187-277.

Alm, J. Sanchez, I., \& De Juan, A. (1995). Economic and noneconomic factors in tax compliance. Kyklos, 48, 3-18.

Alm, J., \& Torgler, B. (2006). Culture differences and tax morale in the United States and in Europe. Journal of Economic Psychology, 27, 224-246.

Anderson, L.R., Rodgers, Y.V., \& Rodriguez, R.R. (2000). Cultural differences in attitudes toward bargaining. Economics Letters, 69, 45-54.

Andreoni, J. (2006). Philanthropy. Handbook of Giving, Reciprocity and Altruism, Amsterdam: North Holland, 1201-1269.

Andreoni, J., \& Vesterlund, L. (2001). Which is the fair sex? Gender differences in altruism. Quarterly Journal of Economics, 116, 293-312.

Auten, G.E., Clotfelter, C., \& Schmalbeck, R.L. (2000). Taxes and philanthropy among the wealthy. In J. Slemrod (Ed.), Does atlas shrug? The economic consequences of taxing the rich (pp. 392424). New York and Cambridge, MA: Russell Sage and Harvard University Press.

Benabou, R., \& Tirole, J. (2006). Belief in a just world and redistributive politics. Quarterly Journal of Economics, 121, 699-746.

Brandts, J., \& Charness, G. (2011). The strategy versus the direct-response method: A first survey of experimental comparisons. Experimental Economics, 14, 375-398.

Brandts, J., Saijo, T., \& Schram, A. (2004). How universal is behavior? A four country comparison of spite and cooperation in voluntary contribution mechanisms. Public Choice, 119, 381-424.

Buckley, E., \& Croson, R. (2006). Income and wealth heterogeneity in the voluntary provision of linear public goods. Journal of Public Economics, 90, 935-955.

Caballero, G. (2016). Opportunities and Effort: ex-post redistribution in the lab. Working paper.

Camerer, C. (2003). Behavioral Game Theory: Experiments on Strategic Interaction. Princeton: Princeton University Press.

Cappelen, A.W., Hole, A.D., Sorensen, E.O., \& Tungodden, B. (2007). The pluralism of fairness ideals: An experimental approach. American Economics Review, 97, 818-827.

Cappelen, A.W., Moene, K., Sorensen, E.O., \& Tungodden, B. (2013). Needs vs entitlements - an international fairness experiment. Journal of the European Economic Association, 11, 574-598.

Cason, T.N., Saijo, T., \& Yamato, T. (2002). Voluntary participation and spite in public good provision experiments: an international comparison. Experimental Economics, 5, 133-153.

Cherry, T.L., Frykblom, P., \& Shogren, J.F. (2002). Hardnose the dictator. American Economic Review, 92, 1218-1221.

Durante, R., Putterman, L., \& van der Weele, L. (2014). Preferences for redistribution and perception of fairness: An experimental study. Journal of the European Economic Association, $12,1059-1086$. 
Eckel, C.C., De Oliveira, A., \& Grossman, P.J. (2007). Is more information always better? An experimental study of charitable giving and Hurricane Katrina. Southern Economic Journal, 74, 388-411.

Erkal, N., Gangadharan, L., \& Nikiforakis, N. (2011). Relative earnings and giving in a real-effort experiment. American Economic Review, 101, 3330-3348.

Esarey, J., Salmon, T., \& Barrilleaux, C. (2012). Social insurance and income redistribution in a laboratory experiment. Political Research Quarterly, 65, 685-698.

Farina, F., \& Grimalda, G. (2011). Preferences for redistribution in the US, Italy, Norway: An experimental study. Working Paper.

Fernández, R. (2010). Does culture matter? Handbook of Social Economics. In Jess Benhabib, Alberto Bisin, Matt Jackson, eds., North Holland.

Fischbacher, U. (2007). z-Tree: Zurich toolbox for ready-made economic experiments. Experimental Economics, 10, 171-178.

Fong, C. (2001). Social preferences, self-interest, and the demand for redistribution. Journal of Public Economics, 82, 225-246.

Fong, C. (2007). Evidence from an experiment on charity to welfare recipients: Reciprocity, altruism and the empathic responsiveness hypothesis. Economic Journal, 117, 1008-1024.

Gneezy, U., \& List, J. (2006). Putting behavioral economics to work: Field evidence on gift exchange. Econometrica, 74, 1365-1384.

Guiso, L., Sapienza, P., \& Zingales, L. (2006). Does culture affect economic outcomes? Journal of Economic Perspectives, 20, 23-48.

Henrich, J., Boyd, R., Bowles, S., Camerer, C., Fehr, E., Gintis, H., \& McElreath, R. (2001). In search of homo economicus: Behavioral experiments in 15 small-scale societies. American Economic Review, 91, 73-78.

Herrmann, B., Thoni, C., \& Gächter, S. (2008). Antisocial punishment across societies. Science, 319, 1362-1367.

Hoffman, E., McCabe, K., Shachat, K., \& Smith, V.L. (1994). Preference, property rights and anonymity in bargaining games. Games and Economic Behavior, 7, 346-380.

Iriberri, N., \& Rey-Biel, P. (2011). The role of role uncertainty in modified dictator games. Experimental Economics, 2, 160-180.

Jakiela, P. (2015). How fair shares compare: Experimental evidence from two cultures. Journal of Economic Behaviour and Organization, 118, 40-54.

Konow, J. (1996). A positive theory of economic fairness. Journal of Economic Behavior and Organization, 31, 13-35.

Konow, J. (2000). Fair shares: Accountability and cognitive dissonance in allocation decisions. American Economics Review, 90, 1072-1091.

Krawczyk, M. (2010). A glimpse through the veil of ignorance: Equality of opportunity and support for redistribution. Journal of Public Economics, 94, 131-141.

Lefgren, L., Sims, D., \& Stoddard, O. (2016). Effort, luck and voting for redistribution. Journal of Public Economics, 143, 89-97.

Roth, A. Prasnihar, V., Okuno-Fujiwara, M., \& Zamir, S. (1991). Bargaining and market behavior in Jerusalem, Ljubljana, Pittsburgh and Tokyo: An experimental study. American Economic Review, 81, 1068-1095.

Rubin, J., \& Sheremeta, R.M. (2016). Principal-agent settings with random shocks. Management Science, 62, 985-999. 
Sheremeta, R.M., \& Uler, N. (2016). The impact of taxes and wasteful government spending on giving. Working Paper.

Smeets, P., Bauer, R., \& Gneezy, U. (2015). Giving behavior of millionaires. Proceedings of the National Academy of Sciences, 34, 10641-10644.

Tonin, M., \& Vlassopoulos, M. (2017). Sharing one’s fortune? An experimental study on earned income and giving. Journal of Behavioral and Experimental Economics, forthcoming.

Ubeda, P. (2014). The consistency of fairness rules: An experimental study. Journal of Economic Psychology, 41, 88-100.

Vesterlund, L. (2006). Why do people give? In Richard Steinberg and Walter W. Powell eds., The Nonprofit Sector, 2nd edition, Yale Press. 
Table 1: The determinants of giving by treatment and country.

\begin{tabular}{|c|c|c|c|c|c|c|c|}
\hline Treatment & INFO & INFO & INFO & NOINFO & NOINFO & NOINFO & NOINFO \\
\hline Country & Spain & US & $\begin{array}{l}\text { Spain } \\
\text { and US }\end{array}$ & Spain & US & $\begin{array}{c}\text { Spain } \\
\text { and US }\end{array}$ & $\begin{array}{c}\text { Spain } \\
\text { and US }\end{array}$ \\
\hline Dependent variable, giving & (1) & (2) & (3) & (4) & (5) & (6) & (7) \\
\hline $\begin{array}{l}\text { usa } \\
\text { [1 if the US] }\end{array}$ & & & $\begin{array}{c}0.62 \\
(2.52)\end{array}$ & & & $\begin{array}{c}-9.73^{* *} \\
(4.74)\end{array}$ & $\begin{array}{c}-9.56^{* *} \\
(4.72)\end{array}$ \\
\hline $\begin{array}{l}\text { own-income } \\
\text { [participant's income from performance] }\end{array}$ & $\begin{array}{c}0.00 \\
(0.10)\end{array}$ & $\begin{array}{c}0.21^{* *} \\
(0.08)\end{array}$ & $\begin{array}{l}0.13^{*} \\
(0.07)\end{array}$ & $\begin{array}{l}-0.18 \\
(0.17)\end{array}$ & $\begin{array}{l}0.25^{* *} \\
(0.10)\end{array}$ & $\begin{array}{c}0.03 \\
(0.12)\end{array}$ & $\begin{array}{c}0.01 \\
(0.13)\end{array}$ \\
\hline $\begin{array}{l}\text { own-luck } \\
\text { [participant’s income from luck] }\end{array}$ & $\begin{array}{c}0.12^{* *} \\
(0.05)\end{array}$ & $\begin{array}{l}0.09 * \\
(0.05)\end{array}$ & $\begin{array}{c}0.09 * * * \\
(0.03)\end{array}$ & $\begin{array}{c}0.18^{* *} \\
(0.09)\end{array}$ & $\begin{array}{c}0.02 \\
(0.07)\end{array}$ & $\begin{array}{c}0.11^{* *} \\
(0.06)\end{array}$ & $\begin{array}{l}0.11^{* *} \\
(0.06)\end{array}$ \\
\hline $\begin{array}{l}\text { other-income } \\
\text { [other participant's income from performance] }\end{array}$ & $\begin{array}{c}-0.30^{* *} \\
(0.12)\end{array}$ & $\begin{array}{c}-0.20^{* *} \\
(0.10)\end{array}$ & $\begin{array}{c}-0.25^{* * *} \\
(0.07)\end{array}$ & & & & \\
\hline $\begin{array}{l}\text { other-luck } \\
\text { [other participant's income from luck] }\end{array}$ & $\begin{array}{l}-0.04 \\
(0.05)\end{array}$ & $\begin{array}{c}0.01 \\
(0.05)\end{array}$ & $\begin{array}{l}-0.01 \\
(0.03)\end{array}$ & & & & \\
\hline $\begin{array}{l}\text { other-total-income } \\
\text { [other participant's total income] }\end{array}$ & & & & $\begin{array}{c}0.10 \\
(0.09)\end{array}$ & $\begin{array}{c}0.01 \\
(0.06)\end{array}$ & $\begin{array}{l}0.09 * \\
(0.05)\end{array}$ & $\begin{array}{c}0.12 \\
(0.10)\end{array}$ \\
\hline $\begin{array}{l}\text { belief } \\
\text { [belief about other participant's luck] }\end{array}$ & & & & & & & $\begin{array}{l}-0.04 \\
(0.12)\end{array}$ \\
\hline $\begin{array}{l}\text { constant } \\
\text { [constant term] }\end{array}$ & $\begin{array}{c}15.84 \\
(11.71)\end{array}$ & $\begin{array}{c}-7.47 \\
(10.65)\end{array}$ & $\begin{array}{c}2.36 \\
(7.90)\end{array}$ & $\begin{array}{c}-6.53 \\
(19.76)\end{array}$ & $\begin{array}{c}-34.26 * * * \\
(10.85)\end{array}$ & $\begin{array}{l}-20.45 \\
(12.54)\end{array}$ & $\begin{array}{l}-21.20 * \\
(12.75)\end{array}$ \\
\hline Observations & 72 & 60 & 132 & 76 & 69 & 145 & 145 \\
\hline
\end{tabular}

Note: * indicates statistical significance at the $10 \%$ level, ** significant at $5 \%$, and *** at $1 \%$. Robust standard errors are in parentheses.

Table 2: The determinants of beliefs in the NOINFO treatment by country.

\begin{tabular}{|c|c|c|c|c|c|c|}
\hline Treatment & NOINFO & NOINFO & NOINFO & NOINFO & NOINFO & NOINFO \\
\hline Country & Spain & US & $\begin{array}{c}\text { Spain } \\
\text { and US }\end{array}$ & Spain & US & $\begin{array}{l}\text { Spain } \\
\text { and US }\end{array}$ \\
\hline Dependent variable, belief & (1) & (2) & (3) & (4) & (5) & (6) \\
\hline $\begin{array}{l}\text { usa } \\
\text { [1 if the US] }\end{array}$ & & & $\begin{array}{c}0.31 \\
(0.33)\end{array}$ & & & $\begin{array}{c}0.62 \\
(0.60)\end{array}$ \\
\hline $\begin{array}{l}\text { own-income } \\
\text { [participant's income from performance] }\end{array}$ & $\begin{array}{c}-0.08 * * * \\
(0.02)\end{array}$ & $\begin{array}{c}-0.06^{* * *} \\
(0.02)\end{array}$ & $\begin{array}{c}-0.07 * * * \\
(0.02)\end{array}$ & $\begin{array}{c}-0.14 * * * \\
(0.04)\end{array}$ & $\begin{array}{l}-0.03 \\
(0.03)\end{array}$ & $\begin{array}{c}-0.07 * * * \\
(0.02)\end{array}$ \\
\hline $\begin{array}{l}\text { own-luck } \\
\text { [participant's income from luck] }\end{array}$ & $\begin{array}{l}-0.01 \\
(0.01)\end{array}$ & $\begin{array}{l}0.00 \\
(0.01)\end{array}$ & $\begin{array}{c}0.00 \\
(0.00)\end{array}$ & $\begin{array}{c}0.00 \\
(0.02)\end{array}$ & $\begin{array}{c}0.01 \\
(0.01)\end{array}$ & $\begin{array}{c}0.01 \\
(0.01)\end{array}$ \\
\hline $\begin{array}{l}\text { other-total-income } \\
\text { [other participant's total income] }\end{array}$ & $\begin{array}{c}0.11^{* * *} \\
(0.02)\end{array}$ & $\begin{array}{c}0.08^{* * *} \\
(0.02)\end{array}$ & $\begin{array}{c}0.09 * * * \\
(0.01)\end{array}$ & $\begin{array}{c}0.21 * * * \\
(0.04)\end{array}$ & $\begin{array}{c}0.07 * * * \\
(0.02)\end{array}$ & $\begin{array}{c}0.10^{* * *} \\
(0.02)\end{array}$ \\
\hline Observations & 76 & 69 & 145 & 76 & 69 & 145 \\
\hline
\end{tabular}


Table 3: The impact of beliefs about luck on giving.

\begin{tabular}{|c|c|c|c|c|}
\hline Treatment & NOINFO & NOINFO & NOINFO & NOINFO \\
\hline Country & $\begin{array}{l}\text { Spain } \\
\text { and US }\end{array}$ & $\begin{array}{c}\text { Spain } \\
\text { and US }\end{array}$ & $\begin{array}{l}\text { Spain } \\
\text { and US }\end{array}$ & $\begin{array}{c}\text { Spain } \\
\text { and US }\end{array}$ \\
\hline Dependent variable, giving & $(1)$ & $(2)$ & (3) & $(4)$ \\
\hline $\begin{array}{l}\text { usa } \\
\quad[1 \text { if the US] }\end{array}$ & $\begin{array}{l}-9.56 * * \\
(4.72)\end{array}$ & $\begin{array}{c}-10.45^{* *} \\
(4.72)\end{array}$ & $\begin{array}{c}-9.40 * * \\
(4.76)\end{array}$ & $\begin{array}{c}-10.04^{* *} \\
(5.01)\end{array}$ \\
\hline belief & -0.04 & -0.32 & -6.81 & -56.25 \\
\hline [belief about other participant's luck] & $(0.12)$ & $(0.34)$ & $(6.27)$ & (34.95) \\
\hline $\begin{array}{l}\text { own-income } \\
\text { [participant's income from performance] }\end{array}$ & $\begin{array}{c}0.01 \\
(0.13)\end{array}$ & $\begin{array}{c}0.00 \\
(0.12)\end{array}$ & $\begin{array}{c}0.00 \\
(0.12)\end{array}$ & $\begin{array}{l}-0.06 \\
(0.13)\end{array}$ \\
\hline $\begin{array}{r}\text { belief } \times \text { own-income } \\
\text { [interaction term] }\end{array}$ & & $\begin{array}{c}0.00 \\
(0.00)\end{array}$ & & $\begin{array}{l}0.16 \\
(0.23)\end{array}$ \\
\hline $\begin{array}{l}\text { own-luck } \\
\text { [participant’s income from luck] }\end{array}$ & $0.11 * *$ & $0.14^{* *}$ & $\begin{array}{l}0.12 * * \\
(0.06)\end{array}$ & $\begin{array}{c}0.16 \\
(0.09)\end{array}$ \\
\hline $\begin{array}{l}\text { belief } \times \text { own-luck } \\
\quad \text { [interaction term] }\end{array}$ & & $\begin{array}{c}0.00 \\
(0.00)\end{array}$ & & $\begin{array}{l}-0.07 \\
(0.12)\end{array}$ \\
\hline $\begin{array}{l}\text { other-total-income } \\
\text { [other participant's total income] }\end{array}$ & $\begin{array}{c}0.12 \\
(0.10)\end{array}$ & $\begin{array}{c}0.12 \\
(0.11)\end{array}$ & $\begin{array}{l}0.16^{*} \\
(0.08)\end{array}$ & $\begin{array}{l}0.08 \\
(0.09)\end{array}$ \\
\hline $\begin{array}{l}\text { belief } \times \text { other-total-income } \\
\text { [interaction term] }\end{array}$ & & $\begin{array}{c}0.00 \\
(0.00)\end{array}$ & & $\begin{array}{c}0.33 \\
(0.22)\end{array}$ \\
\hline $\begin{array}{l}\text { constant } \\
\text { [constant term] }\end{array}$ & $\begin{array}{l}-21.20^{*} \\
(12.75)\end{array}$ & $\begin{array}{l}-21.01 * \\
(12.49)\end{array}$ & $\begin{array}{l}-20.83 \\
(12.77)\end{array}$ & $\begin{array}{l}-10.35 \\
(11.39)\end{array}$ \\
\hline Observations & 145 & 145 & 145 & 145 \\
\hline
\end{tabular}


Table 4: Personal characteristics by country.

\begin{tabular}{|c|c|c|c|c|c|c|c|}
\hline \multirow[t]{2}{*}{ Country } & \multicolumn{3}{|c|}{ Spain } & \multicolumn{3}{|c|}{ US } & \multirow{2}{*}{$\frac{\text { Mann-Whitney test }}{\text { p-value }}$} \\
\hline & Mean & Min & Max & Mean & Min & Max & \\
\hline $\begin{array}{l}\text { hard } \\
\text { [how hard you worked on the task] }\end{array}$ & $\begin{array}{c}5.66 \\
(1.79)\end{array}$ & 1 & 9 & $\begin{array}{c}7.96 \\
(2.15)\end{array}$ & 1 & 10 & $0.00^{* * *}$ \\
\hline $\begin{array}{l}\text { female } \\
\quad[1 \text { if female] }\end{array}$ & $\begin{array}{c}0.57 \\
(0.50)\end{array}$ & 0 & 1 & $\begin{array}{c}0.53 \\
(0.50)\end{array}$ & 0 & 1 & 0.53 \\
\hline $\begin{array}{l}\text { age } \\
\text { [age of a participant] }\end{array}$ & $\begin{array}{l}21.52 \\
(3.11)\end{array}$ & 18 & 38 & $\begin{array}{l}21.51 \\
(3.55)\end{array}$ & 18 & 43 & 0.85 \\
\hline $\begin{array}{l}\text { income } \\
\text { [categorical income variable] }\end{array}$ & $\begin{array}{l}1.49 \\
(0.68)\end{array}$ & 1 & 3 & $\begin{array}{c}1.78 \\
(0.79)\end{array}$ & 1 & 3 & $0.00^{* * *}$ \\
\hline $\begin{array}{l}\text { proportion } \\
\text { [proportion of income from work] }\end{array}$ & $\begin{array}{c}2.62 \\
(1.36)\end{array}$ & 1 & 4 & $\begin{array}{l}2.50 \\
(1.33)\end{array}$ & 1 & 4 & 0.48 \\
\hline $\begin{array}{l}\text { family } \\
\text { [importance of family] }\end{array}$ & $\begin{array}{c}2.07 \\
(0.90)\end{array}$ & 1 & 5 & $\begin{array}{l}1.88 \\
(1.12)\end{array}$ & 1 & 6 & $0.01^{* * *}$ \\
\hline $\begin{array}{l}\text { religion } \\
\text { [importance of religion] }\end{array}$ & $\begin{array}{c}5.39 \\
(1.11)\end{array}$ & 1 & 6 & $\begin{array}{c}4.05 \\
(1.72)\end{array}$ & 1 & 6 & $0.00^{* * *}$ \\
\hline $\begin{array}{l}\text { leisure } \\
\text { [importance of leisure time] }\end{array}$ & $\begin{array}{c}2.55 \\
(0.76)\end{array}$ & 1 & 5 & $\begin{array}{l}2.40 \\
(1.01)\end{array}$ & 1 & 6 & $0.10^{*}$ \\
\hline $\begin{array}{l}\text { politics } \\
\quad \text { [political view] }\end{array}$ & $\begin{array}{c}3.03 \\
(1.25)\end{array}$ & 1 & 7 & $\begin{array}{c}3.39 \\
(1.35)\end{array}$ & 1 & 7 & $0.03 * *$ \\
\hline $\begin{array}{l}\text { work } \\
\text { [importance of work] }\end{array}$ & $\begin{array}{c}3.39 \\
(1.37)\end{array}$ & 1 & 7 & $\begin{array}{c}3.64 \\
(1.32)\end{array}$ & 1 & 6 & $0.06^{*}$ \\
\hline $\begin{array}{l}\text { luck } \\
\text { [importance of luck] }\end{array}$ & $\begin{array}{c}3.81 \\
(1.47)\end{array}$ & 1 & 7 & $\begin{array}{c}4.69 \\
(1.49)\end{array}$ & 1 & 7 & $0.00^{* * *}$ \\
\hline $\begin{array}{l}\text { government } \\
\text { [responsibilities of government] }\end{array}$ & $\begin{array}{c}2.55 \\
(1.43)\end{array}$ & 1 & 7 & $\begin{array}{c}3.37 \\
(1.67)\end{array}$ & 1 & 7 & $0.00^{* * *}$ \\
\hline
\end{tabular}

Note: * indicates statistical significance at $10 \%$ level, ** at 5\%; and *** at $1 \%$. Standard deviation in parentheses. Spain has 148 and US has 119 data points. 
Table 5: Personal characteristics and giving.

\begin{tabular}{|c|c|c|c|c|}
\hline Treatment & $\begin{array}{l}\text { INFO and } \\
\text { NOINFO }\end{array}$ & $\begin{array}{l}\text { INFO and } \\
\text { NOINFO }\end{array}$ & $\begin{array}{l}\text { INFO and } \\
\text { NOINFO }\end{array}$ & $\begin{array}{l}\text { INFO and } \\
\text { NOINFO }\end{array}$ \\
\hline Country & $\begin{array}{c}\text { Spain } \\
\text { and US }\end{array}$ & $\begin{array}{c}\text { Spain } \\
\text { and US }\end{array}$ & $\begin{array}{c}\text { Spain } \\
\text { and US }\end{array}$ & $\begin{array}{l}\text { Spain } \\
\text { and US }\end{array}$ \\
\hline Dependent variable, giving & $(1)$ & $(2)$ & (3) & $(4)$ \\
\hline $\begin{array}{l}\text { usa } \\
\text { [1 if the US] }\end{array}$ & $\begin{array}{c}2.25 \\
(3.47)\end{array}$ & $\begin{array}{c}2.63 \\
(3.40)\end{array}$ & $\begin{array}{c}2.52 \\
(3.88)\end{array}$ & $\begin{array}{c}4.95 \\
(4.24)\end{array}$ \\
\hline $\begin{array}{l}\text { noinfo } \\
\quad[1 \text { if NOINFO] }\end{array}$ & $\begin{array}{l}6.14^{*} \\
(3.69)\end{array}$ & $\begin{array}{c}5.42 \\
(3.54)\end{array}$ & $\begin{array}{c}5.21 \\
(3.39)\end{array}$ & $\begin{array}{c}6.10 \\
(3.76)\end{array}$ \\
\hline $\begin{array}{l}\text { usa } \times \text { noinfo } \\
\quad \text { [interaction term] }\end{array}$ & $\begin{array}{c}-12.42 * * \\
(5.48)\end{array}$ & $\begin{array}{c}-11.93^{* *} \\
(5.43)\end{array}$ & $\begin{array}{c}-11.19 * * \\
(5.12)\end{array}$ & $\begin{array}{c}-12.02^{* *} \\
(5.84)\end{array}$ \\
\hline $\begin{array}{l}\text { own-income } \\
\text { [participant's income from performance] }\end{array}$ & & $\begin{array}{c}0.12 \\
(0.08)\end{array}$ & $\begin{array}{c}0.11 \\
(0.07)\end{array}$ & $\begin{array}{c}0.06 \\
(0.08)\end{array}$ \\
\hline $\begin{array}{l}\text { own-luck } \\
\text { [participant’s income from luck] }\end{array}$ & & $\begin{array}{c}0.11^{* * *} \\
(0.03)\end{array}$ & $\begin{array}{c}0.10^{* * *} \\
(0.03)\end{array}$ & $\begin{array}{c}0.10^{* * *} \\
(0.04)\end{array}$ \\
\hline $\begin{array}{l}\text { other-total-income } \\
\text { [other participant's total income] }\end{array}$ & & $\begin{array}{c}0.02 \\
(0.03)\end{array}$ & $\begin{array}{c}0.02 \\
(0.03)\end{array}$ & $\begin{array}{c}0.02 \\
(0.04)\end{array}$ \\
\hline $\begin{array}{l}\text { hard } \\
\text { [how hard you worked on the task] }\end{array}$ & & & $\begin{array}{c}0.70 \\
(0.63)\end{array}$ & $\begin{array}{c}0.56 \\
(0.65)\end{array}$ \\
\hline $\begin{array}{l}\text { female } \\
\quad[1 \text { if female }]\end{array}$ & & & $\begin{array}{l}-4.95 * \\
(2.56)\end{array}$ & $\begin{array}{l}-1.62 \\
(2.81)\end{array}$ \\
\hline $\begin{array}{l}\text { age } \\
\text { [age of a participant] }\end{array}$ & & & $\begin{array}{c}0.57 \\
(0.37)\end{array}$ & $\begin{array}{c}0.22 \\
(0.45)\end{array}$ \\
\hline $\begin{array}{l}\text { income } \\
\text { [categorical income variable] }\end{array}$ & & & $\begin{array}{c}0.94 \\
(1.63)\end{array}$ & $\begin{array}{c}0.49 \\
(1.87)\end{array}$ \\
\hline $\begin{array}{l}\text { proportion } \\
\text { [proportion of income from work] }\end{array}$ & & & $\begin{array}{c}0.9 \\
(0.98)\end{array}$ & $\begin{array}{c}0.84 \\
(1.09)\end{array}$ \\
\hline $\begin{array}{l}\text { family } \\
\text { [importance of family] }\end{array}$ & & & $\begin{array}{l}-0.67 \\
(1.35)\end{array}$ & $\begin{array}{c}0.85 \\
(1.49)\end{array}$ \\
\hline $\begin{array}{l}\text { religion } \\
\text { [importance of religion] }\end{array}$ & & & $\begin{array}{c}0.76 \\
(0.90)\end{array}$ & $\begin{array}{c}0.78 \\
(1.11)\end{array}$ \\
\hline $\begin{array}{l}\text { leisure } \\
\text { [importance of leisure time] }\end{array}$ & & & $\begin{array}{c}1.73 \\
(1.22)\end{array}$ & $\begin{array}{c}1.68 \\
(1.39)\end{array}$ \\
\hline $\begin{array}{l}\text { politics } \\
\text { [political view] }\end{array}$ & & & $\begin{array}{l}-0.17 \\
(1.04)\end{array}$ & $\begin{array}{c}0.37 \\
(1.12)\end{array}$ \\
\hline $\begin{array}{l}\text { work } \\
\text { [importance of work] }\end{array}$ & & & $\begin{array}{c}1.05 \\
(0.89)\end{array}$ & $\begin{array}{c}1.17 \\
(0.96)\end{array}$ \\
\hline $\begin{array}{l}\text { luck } \\
\text { [importance of luck] }\end{array}$ & & & $\begin{array}{l}-0.97 \\
(0.91)\end{array}$ & $\begin{array}{l}-0.97 \\
(0.97)\end{array}$ \\
\hline $\begin{array}{l}\text { government } \\
\text { [responsibilities of government] }\end{array}$ & & & $\begin{array}{l}-1.25 \\
(0.86)\end{array}$ & $\begin{array}{l}-1.67 * \\
(0.95)\end{array}$ \\
\hline constant & $\begin{array}{c}-11.99 * * * \\
(3.31)\end{array}$ & $\begin{array}{c}-23.84 * * * \\
(8.60)\end{array}$ & $\begin{array}{c}-42.68^{* *} \\
(17.44)\end{array}$ & $\begin{array}{l}-36.61^{*} \\
(20.23)\end{array}$ \\
\hline Observations & 277 & 277 & 267 & 209 \\
\hline
\end{tabular}


Figure 1: Average giving by treatment and country.

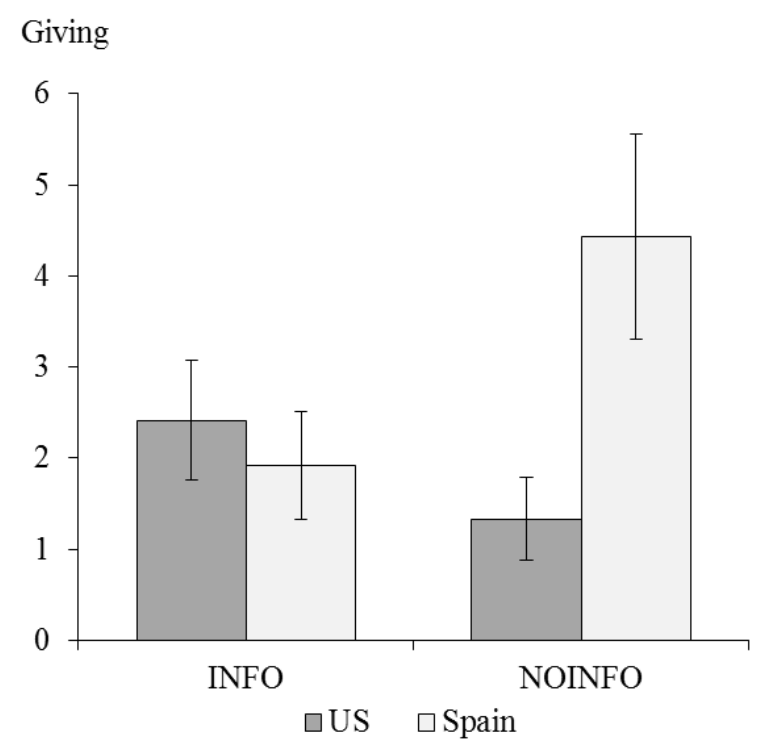

Figure 2: Distribution of giving by treatment and country.
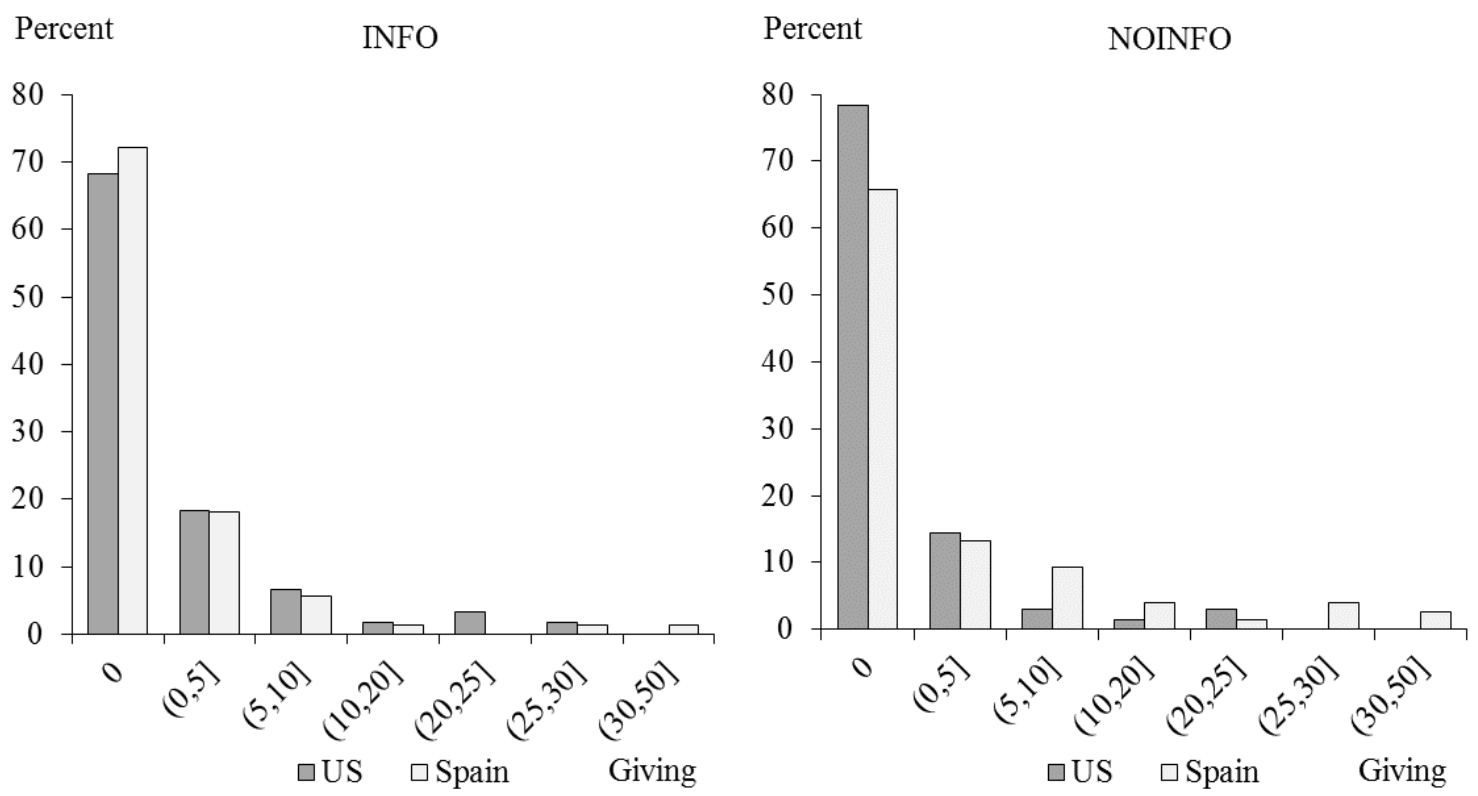


\section{Appendix A - Instructions for the NOINFO treatment}

Below you can find the instructions for the treatment with no information regarding the determinants of others' income. Instructions for the treatment with information are identical with the exception that the screen in Part II containing information about the other subjects' earnings also includes the number of correct answer and the random number of the paired subject. Instructions for the treatment with information did not contain a Part III of the experiment, where beliefs were elicited.

\section{General Instructions}

Thank you for agreeing to participate in this experiment. Several research agencies have provided funds for this research. Please make sure your cell phones are turned off to avoid interruptions during the proceedings.

This experiment deals with individual decision making. Your participation in this experiment is voluntary. As you know, you will be compensated for your participation; if you read the instructions carefully, you can, depending on yours and other participants' decisions, earn a considerable amount of money in addition to the $\$ 7$ participation fee. The currency used in the experiment is tokens. Tokens will be converted to US dollars at a rate of $\mathbf{1}$ token to 0.15 US dollars.

The experiment consists of two parts. You will be provided with instructions for Part I of the experiment. After Part I of the experiment is over, you will be provided with instructions for Part II. While you wait to be paid, you will be asked to fill out a questionnaire.

In our experiment, all records will be linked to an anonymous subject ID. At the end of the experiment, you will be paid privately and anonymously. The experimenter will get help from one of her assistants to distribute the payments. The assistant does not know which ID belongs to which participant. The assistant will place the earnings of participants in envelopes with matching ID numbers. After closing the envelopes, the assistant will pass the envelopes to the experimenter. Therefore, nobody, not even the experimenter, will be able to link your decisions to your name during or after the experiment.

Please do not communicate with the other participants during the experiments. Should you have any questions, please raise your hand. At the end of the experiment we will call you, one at a time, to pay you in private.

\section{Pre-instructions}

In the first part of this experiment you will be asked to count the sum of "a" and "d" characters in 50-character sequences. Characters include letters, punctuation marks, numbers, and symbols. Below we provide some examples. Please make sure you understand how we have calculated the sum of "a" and "d" characters in each sequence.

\begin{tabular}{|c|c|c|}
\hline $\begin{array}{c}\text { sequence } \\
\#\end{array}$ & 50-characters sequence & $\begin{array}{c}\text { total number of } \\
\text { "a" and "d" } \\
\text { characters }\end{array}$ \\
\hline 1 & aaaaaaaaadddaaaaaddaaaaaaaaaaaaaaaaaaaaaaaaaaaaaa & 50 \\
\hline 2 & 7 po6df^gaips78fadfsdfs\&fsdasdftyhgdua*gfrtg(tratra & 12 \\
\hline 3 & p@=jsjd8fjaalkjdflkjds890aaaaaaaatrhtr-taatrgtaaaa & 19 \\
\hline 4 & Las9-fakjasklfjalsdjlkjaakljalksaljl=-ddt+gtraaart & 14 \\
\hline
\end{tabular}

Before we start, you will now go through a practice round. Although your final earnings do not depend on the number of correct counts in this practice round, you should try to correctly count all sequences to get practice. We ask you to input into the computer the sum of "a" and "d" characters beside each sequence number, as shown in the following figure. 


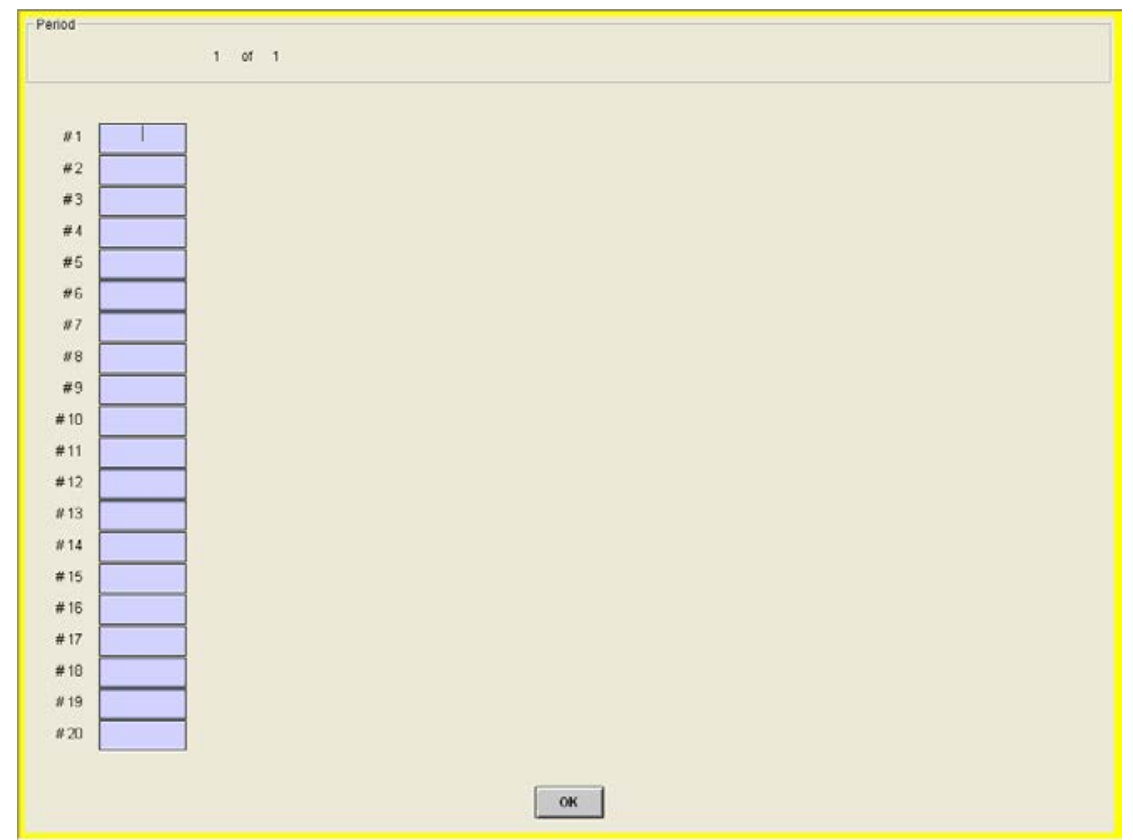

When you finish, the computer will display the correct sum of "a" and "d" characters next to each sequence. If all your answers are correct, both columns should be the same.

Even if you use the following page to make notes, please remember to input each number in the computer as soon as you have calculated it.

\section{Instructions Part I}

In this Part I of the experiment, you will be provided with $\mathbf{3 0 0}$ character sequences. During $\mathbf{3 0}$ minutes you will be asked to count the sum of "a" and "d" characters in each sequence. Your earnings from Part I will depend on your result. Your result will be computed by adding a random number $\mathbf{X}$ to the number of your correct counts:

(your result) $=$ (your number of correct counts) + (your random number $\mathrm{X})$

where your random number $X$ is randomly drawn by the computer and it can be either $\mathbf{- 5 0 , - 2 5 , 0 , + 2 5 , ~ o r ~}+\mathbf{5 0}$. Each of these numbers is equally likely to be drawn and may differ for each participant. At the end of this part the computer will make one separate and independent random draw for each participant.

For example, if you correctly count the sum "a" and "d" characters in 82 sequences and the random number X selected by the computer is -25 , your result will be $57=(82-25)$, while if the random number selected by the computer is +50 your result will be $132=(82+50)$. Numbers in this example are just for illustrative purposes and do not intend to indicate how the computer will choose the random number.

After the 30 minutes of the experiment, the computer will randomly draw your random number $\mathrm{X}$ and will calculate your result based on your random number and your number of correct counts. Then the computer will calculate earnings of each participant. Your earnings from Part I are calculated by multiplying your result by 1 token:

(your earnings in Part I) $=($ your result $* 1$ token $)$

Note: if your random number is negative and the number of correct counts is less than your random number then your result will be negative. In such a case, the computer will set your earnings for this part of the experiment to zero.

You will have 30 minutes to count the sum of "a" and "d" characters in the 300 sequences we will show you. In any case, you can stop counting characters whenever you want and you do not have to continue until the end. What we 
ask you is to keep quite during the 30 minutes. In case you decide to take a break, we have left some newspapers for you to read (you are also allowed to take books and lecture notes and read).

The sentences are provided in paper sheets. You are allowed to use a pen. However, you are asked to enter the sum of "a" and "d" letters before the 30 minutes end to be able to get your earnings.

Please wait until the experimenter gives the start sign.

\section{Instructions Part II}

In this Part II of the experiment you are randomly paired with another participant. To preserve anonymity, neither of you will ever learn with whom you are paired with.

At the beginning of Part II, the computer will display your number of correct counts, your random number (which the computer randomly drew from -50, -25, 0, +25, or +50), and your result in Part I. Remember, the result from Part I is:

(your result $)=($ your number of correct counts $)+($ your random number $\mathrm{X})$

Finally, the computer will display your earnings. Remember, earnings from Part I are calculated by multiplying your result by 1 token:

(your earnings in Part I) $=($ your result $) *(1$ token $)$

The computer will also display the result, and the earnings in Part I of your paired participant. The computer WILL NOT show you the number of correct answer or the random number of your paired participant. Remember that your paired participant's random number may be different from your random number since the computer makes two separate random draws: one for you and one for your paired participant.

An example of the display screen is shown below:

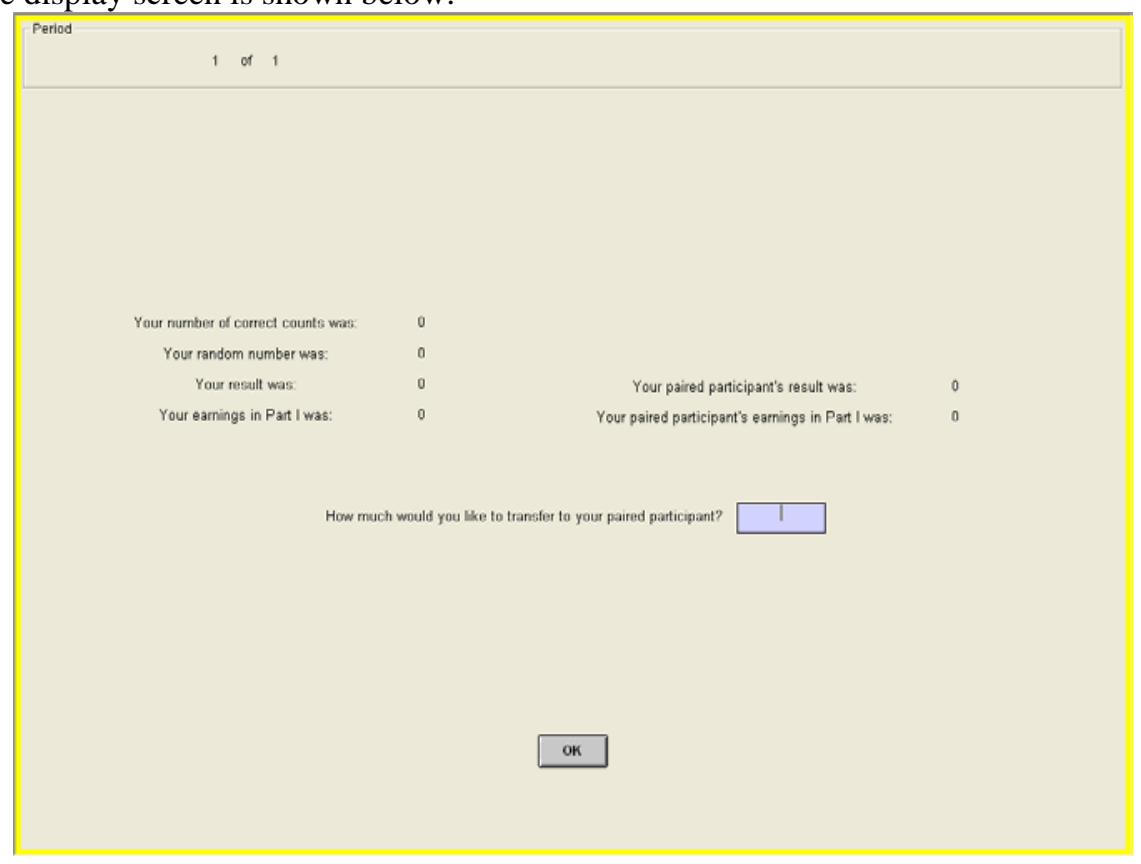

Once the computer displays the screen above, you will make a decision on how much you would like to transfer from your earnings to the other participant's earnings. You will be able to transfer any amount you like. For example, 
suppose your earnings from Part I is 100 tokens and if the other participant's earnings is 120 tokens. If you enter a transfer of 15 your final earnings will be 85 (=100-15), and the other participant's final earnings will be 135 (=120+15).

Numbers in this example are just for illustrative purposes and do not intend to indicate how you should make your decisions.

Although both you and your paired participant will make the transfer decisions, the computer will randomly implement only one decision made by either you or your paired participant. However, you will not know whose decision will be implemented until the end of the experiment. Since your decision is implemented with 50\% probability, you should pay careful attention to the transfer decision you make.

To summarize, if your decision is randomly picked, then your transfer will decrease your earnings and it will increase your paired participant's earnings. However, you will not get anything from your paired participant's transfer since his/her decision is not implemented. Similarly, if your paired participant's decision is randomly picked, his/her transfer will increase your earnings, and it will decrease his/her earnings. However, you will not transfer anything to your paired participant since your decision is not implemented.

At the end of the experiment you will be paid the total amount of your final income in private and in cash.

In our experiment, all records will be linked to an anonymous subject ID. At the end of the experiment, you will be paid privately and anonymously. The experimenter will get help from one of her assistants to distribute the payments. The assistant does not know which ID belongs to which participant. The assistant will place the earnings of participants in envelopes with matching ID numbers. After closing the envelopes, the assistant will pass the envelopes to the experimenter. Therefore, nobody, not even the experimenter, be able to link your decisions to your name during or after the experiment.

\section{Part III (only for the NOINFO treatment)}

In the screen you just saw, the computer only showed you the result and the earnings in Part I of your paired participant. The computer did not show you the random number of your paired participant.

In this Part II we ask you to make a prediction about the random number of your paired participant. If your guessing is correct you will receive 10 extra experimental points which will add up to your final earnings. If your prediction is not correct you will not earn any additional point.

Remember that your paired participant's random number can be different from yours since the computer chooses them independently among $-50,-25,0,+25$ or +50 . 


\section{Appendix B - Questionnaire}

1. How hard did you work in the first part of the experiment in a scale from 1 to 10 ?
a. 1
b. 2
c. 3
d. 4
e. 5
f. 6
g. 7
h. 8
i. 9
j. 10

2. Gender
a. male
b. female

3. Age

4. Average Monthly Income (including all income sources such as parent's expenses for you)
a. less than $\$ 500$
b. between $\$ 500-1000$
c. more than $\$ 1000$

5. What proportion of your income comes from your own work
a. less than $20 \%$
b. between $20 \%$ and $50 \%$
c. between $50 \%$ and $70 \%$
d. all or almost all

6. What is the importance of family in your life:
a. extremely important
b. very important
c. important
d. somewhat important
e. not very important
f. not important at all

7. What is the importance of religion in your life:
a. extremely important
b. very important
c. important
d. somewhat important
e. not very important
f. not important at all

8. What is the importance of leisure time in your life:
a. extremely important
b. very important
c. important
d. somewhat important
e. not very important
f. not important at all 
9. In political matters, people talk of "the left" and "the right." How would you place your views on this scale, generally speaking?
a. extreme left
b. left
c. left-center
d. center
e. right-center
f. right
g. extreme right

10. Please tell us whether you think the following change is desirable: "Less importance placed on work in our lives"
a. extremely desirable
b. very desirable
c. desirable
d. indifferent
e. not very desirable
f. undesirable
g. extremely undesirable

11. How would you place your views on this: "Hard work doesn't bring success - it's more a matter of luck and connections"
a. I completely agree
b. I agree most of the times
c. I agree
d. I am indifferent
e. I disagree
f. I disagree most of the times
g. I completely disagree

12. How would you place your views on this: "The government should take more responsibility to ensure that everyone is provided for"
a. I completely agree
b. I agree most of the times
c. I agree
d. I am indifferent
e. I disagree
f. I disagree most of the times
g. I completely disagree

13. In what country or region were you born?
a. North America
b. Central/South America
c. Australia/ New Zealand
d. Other Pacific Nation
e. South-East Asia
f. South Asia
g. Other Asia
h. Western Europe
i. Northern Europe
j. Eastern Europe
k. Africa 


\section{Appendix C - Additional analysis}

Table C1 reports the same regressions as in Table 1, but using OLS instead of Tobit.

Qualitative results are very similar.

Table C1: The determinants of giving by treatment and country (OLS).

\begin{tabular}{|c|c|c|c|c|c|c|c|}
\hline Treatment & INFO & INFO & INFO & NOINFO & NOINFO & NOINFO & NOINFO \\
\hline Country & Spain & US & $\begin{array}{c}\text { Spain } \\
\text { and US }\end{array}$ & Spain & US & $\begin{array}{c}\text { Spain } \\
\text { and US }\end{array}$ & $\begin{array}{c}\text { Spain } \\
\text { and US }\end{array}$ \\
\hline Dependent variable, giving & (1) & (2) & (3) & (4) & (5) & (6) & (7) \\
\hline $\begin{array}{l}\text { usa } \\
\text { [1 if the US] }\end{array}$ & & & $\begin{array}{c}0.21 \\
(0.82)\end{array}$ & & & $\begin{array}{c}-2.83^{* *} \\
(1.16)\end{array}$ & $\begin{array}{l}-2.72^{* *} \\
(1.15)\end{array}$ \\
\hline $\begin{array}{l}\text { own-income } \\
\text { [participant's income from performance] }\end{array}$ & $\begin{array}{c}0.01 \\
(0.03)\end{array}$ & $\begin{array}{l}0.04^{*} \\
(0.02)\end{array}$ & $\begin{array}{c}0.03 \\
(0.02)\end{array}$ & $\begin{array}{l}-0.02 \\
(0.06)\end{array}$ & $\begin{array}{l}0.03^{*} \\
(0.01)\end{array}$ & $\begin{array}{c}0.00 \\
(0.03)\end{array}$ & $\begin{array}{l}-0.02 \\
(0.04)\end{array}$ \\
\hline $\begin{array}{l}\text { own-luck } \\
\text { [participant's income from luck] }\end{array}$ & $\begin{array}{l}0.03^{* *} \\
(0.02)\end{array}$ & $\begin{array}{c}0.02 \\
(0.02)\end{array}$ & $\begin{array}{l}0.03^{* *} \\
(0.01)\end{array}$ & $\begin{array}{c}0.04 \\
(0.03)\end{array}$ & $\begin{array}{l}-0.01 \\
(0.02)\end{array}$ & $\begin{array}{c}0.02 \\
(0.02)\end{array}$ & $\begin{array}{c}0.02 \\
(0.02)\end{array}$ \\
\hline $\begin{array}{l}\text { other-income } \\
\text { [other participant's income from performance] }\end{array}$ & $\begin{array}{c}-0.10^{* * *} \\
(0.04)\end{array}$ & $\begin{array}{l}-0.08^{*} \\
(0.04)\end{array}$ & $\begin{array}{c}-0.09 * * * \\
(0.03)\end{array}$ & & & & \\
\hline $\begin{array}{l}\text { other-luck } \\
\text { [other participant's income from luck] }\end{array}$ & $\begin{array}{l}-0.02 \\
(0.02)\end{array}$ & $\begin{array}{l}-0.01 \\
(0.02)\end{array}$ & $\begin{array}{l}-0.02 \\
(0.01)\end{array}$ & & & & \\
\hline $\begin{array}{l}\text { other-total-income } \\
\text { [other participant's total income] }\end{array}$ & & & & $\begin{array}{c}0.04 \\
(0.04)\end{array}$ & $\begin{array}{l}-0.01 \\
(0.01)\end{array}$ & $\begin{array}{c}0.03 \\
(0.02)\end{array}$ & $\begin{array}{l}0.05^{*} \\
(0.03)\end{array}$ \\
\hline $\begin{array}{l}\text { belief } \\
\text { [belief about other participant's luck] }\end{array}$ & & & & & & & $\begin{array}{l}-0.03 \\
(0.03)\end{array}$ \\
\hline $\begin{array}{l}\text { constant } \\
\text { [constant term] }\end{array}$ & $\begin{array}{c}9.48 * * * \\
(3.14)\end{array}$ & $\begin{array}{c}5.10 \\
(4.20)\end{array}$ & $\begin{array}{c}6.98^{* * *} \\
(2.64)\end{array}$ & $\begin{array}{c}1.92 \\
(6.60)\end{array}$ & $\begin{array}{c}-0.26 \\
(1.01)\end{array}$ & $\begin{array}{c}1.92 \\
(2.84)\end{array}$ & $\begin{array}{c}1.20 \\
(2.68)\end{array}$ \\
\hline Observations & 72 & 60 & 132 & 76 & 69 & 145 & 145 \\
\hline
\end{tabular}


Table C2 reports the same regressions as in Table 2, but using OLS instead of Logit and

Ordered Logit. Qualitative results are very similar.

Table C2: The determinants of beliefs in the NOINFO treatment by country (OLS).

\begin{tabular}{lcccccc}
\hline \hline Treatment & NOINFO & NOINFO & NOINFO & NOINFO & NOINFO & NOINFO \\
\hline Country & Spain & US & $\begin{array}{c}\text { Spain } \\
\text { and US }\end{array}$ & Spain & US & $\begin{array}{c}\text { Spain } \\
\text { and US }\end{array}$ \\
\hline Dependent variable, belief & $(1)$ & $(2)$ & $(3)$ & $(4)$ & $(5)$ & $(6)$ \\
\hline usa & & & 3.09 & & & 0.04 \\
$\quad$ 1 if the US] & & & $(2.73)$ & & & $(0.05)$ \\
own-income & $-0.49^{* * *}$ & $-0.40^{* * *}$ & $-0.46^{* * *}$ & $-0.01^{* * *}$ & 0.00 & $-0.00^{* * *}$ \\
$\quad$ [participant's income from performance] & $(0.11)$ & $(0.14)$ & $(0.09)$ & $(0.00)$ & $(0.00)$ & $(0.00)$ \\
own-luck & -0.04 & 0.02 & 0.00 & 0.00 & 0.00 & 0.00 \\
$\quad$ [participant's income from luck] & $(0.04)$ & $(0.05)$ & $(0.03)$ & $(0.00)$ & $(0.00)$ & $(0.00)$ \\
other-total-income & $0.75^{* * *}$ & $0.68^{* * *}$ & $0.71^{* * *}$ & $0.01^{* * *}$ & $0.01^{* * *}$ & $0.01^{* * *}$ \\
$\quad$ [other participant's total income] & $(0.05)$ & $(0.05)$ & $(0.03)$ & $(0.00)$ & $(0.00)$ & $(0.00)$ \\
constant & $-21.02^{* *}$ & -20.1 & $-21.06^{* *}$ & 0.23 & -0.26 & -0.04 \\
$\quad$ [constant term] & $(10.34)$ & $(14.20)$ & $(8.81)$ & $(0.17)$ & $(0.20)$ & $(0.13)$ \\
\hline Observations & 76 & 69 & 145 & 76 & 145 & 76 \\
\hline Norv
\end{tabular}

Note: * indicates statistical significance at the $10 \%$ level, ${ }^{* *}$ significant at $5 \%$, and ${ }^{* * *}$ at $1 \%$. Robust standard errors are in parentheses. Regressions (1)-(3) use belief $=\{-50,-25,0,25,50\}$ and regressions (4)-(6) use belief $=\{0,1\}$. 
Table C3 reports the same regressions as in Table 3, but using OLS instead of Tobit.

Qualitative results are very similar.

Table C3: The impact of beliefs about luck on giving (OLS).

\begin{tabular}{|c|c|c|c|c|}
\hline Treatment & NOINFO & NOINFO & NOINFO & NOINFO \\
\hline Country & $\begin{array}{c}\text { Spain } \\
\text { and US }\end{array}$ & $\begin{array}{l}\text { Spain } \\
\text { and US }\end{array}$ & $\begin{array}{l}\text { Spain } \\
\text { and US }\end{array}$ & $\begin{array}{l}\text { Spain } \\
\text { and US }\end{array}$ \\
\hline Dependent variable, giving & $(1)$ & $(2)$ & (3) & $(4)$ \\
\hline [1 if the US] & $\begin{array}{l}-2.72 * * \\
(1.15)\end{array}$ & $\begin{array}{c}-2.81^{* *} \\
(1.22)\end{array}$ & $\begin{array}{c}-2.74^{* *} \\
(1.18)\end{array}$ & $\begin{array}{c}-2.75 * * \\
(1.33)\end{array}$ \\
\hline $\begin{array}{l}\text { belief } \\
\text { [belief about other participant’s luck] }\end{array}$ & $\begin{array}{l}-0.03 \\
(0.03)\end{array}$ & $\begin{array}{l}-0.13 \\
(0.12)\end{array}$ & $\begin{array}{l}-1.96 \\
(1.42)\end{array}$ & $\begin{array}{l}-10.28 \\
(8.90)\end{array}$ \\
\hline $\begin{array}{l}\text { own-income } \\
\text { [participant's income from performance] }\end{array}$ & $\begin{array}{l}-0.02 \\
(0.04)\end{array}$ & $\begin{array}{l}-0.01 \\
(0.04)\end{array}$ & $\begin{array}{l}-0.01 \\
(0.03)\end{array}$ & $\begin{array}{l}-0.01 \\
(0.03)\end{array}$ \\
\hline $\begin{array}{l}\text { belief } \times \text { own-income } \\
{[\text { interaction term }]}\end{array}$ & & $\begin{array}{c}0.00 \\
(0.00)\end{array}$ & & $\begin{array}{c}0.01 \\
(0.07)\end{array}$ \\
\hline $\begin{array}{l}\text { own-luck } \\
\text { [participant's income from luck] }\end{array}$ & $\begin{array}{c}0.02 \\
(0.02)\end{array}$ & $\begin{array}{c}0.02 \\
(0.02)\end{array}$ & $\begin{array}{c}0.02 \\
(0.02)\end{array}$ & $\begin{array}{c}0.03 \\
(0.02)\end{array}$ \\
\hline $\begin{array}{l}\text { belief } \times \text { own-luck } \\
\quad \text { [interaction term] }\end{array}$ & & $\begin{array}{c}0.00 \\
(0.00)\end{array}$ & & $\begin{array}{l}-0.02 \\
(0.03)\end{array}$ \\
\hline $\begin{array}{l}\text { other-total-income } \\
\text { [other participant's total income] }\end{array}$ & $\begin{array}{l}0.05^{*} \\
(0.03)\end{array}$ & $\begin{array}{l}0.05^{*} \\
(0.03)\end{array}$ & $\begin{array}{l}0.04 * \\
(0.02)\end{array}$ & $\begin{array}{c}0.02 \\
(0.02)\end{array}$ \\
\hline $\begin{array}{l}\text { belief } \times \text { other-total-income } \\
\text { [interaction term] }\end{array}$ & & $\begin{array}{c}0.00 \\
(0.00)\end{array}$ & & $\begin{array}{c}0.08 \\
(0.06)\end{array}$ \\
\hline $\begin{array}{l}\text { constant } \\
\text { [constant term] }\end{array}$ & $\begin{array}{c}1.2 \\
(2.68) \\
\end{array}$ & $\begin{array}{c}0.39 \\
(2.95) \\
\end{array}$ & $\begin{array}{c}1.84 \\
(2.84) \\
\end{array}$ & $\begin{array}{c}3.30 \\
(2.41) \\
\end{array}$ \\
\hline Observations & 145 & 145 & 145 & 145 \\
\hline
\end{tabular}


Table C5 reports the same regressions as in Table 5, but using OLS instead of Tobit.

Qualitative results are very similar.

Table C5: Personal characteristics and giving (OLS).

\begin{tabular}{|c|c|c|c|c|}
\hline Treatment & $\begin{array}{l}\text { INFO and } \\
\text { NOINFO }\end{array}$ & $\begin{array}{l}\text { INFO and } \\
\text { NOINFO }\end{array}$ & $\begin{array}{l}\text { INFO and } \\
\text { NOINFO }\end{array}$ & $\begin{array}{l}\text { INFO and } \\
\text { NOINFO }\end{array}$ \\
\hline Country & $\begin{array}{l}\text { Spain } \\
\text { and US }\end{array}$ & $\begin{array}{l}\text { Spain } \\
\text { and US }\end{array}$ & $\begin{array}{c}\text { Spain } \\
\text { and US }\end{array}$ & $\begin{array}{l}\text { Spain } \\
\text { and US }\end{array}$ \\
\hline Dependent variable, giving & (1) & (2) & (3) & (4) \\
\hline $\begin{array}{l}\text { usa } \\
\text { [1 if the US] }\end{array}$ & $\begin{array}{c}0.50 \\
(0.89)\end{array}$ & $\begin{array}{c}0.58 \\
(0.87)\end{array}$ & $\begin{array}{c}0.68 \\
(0.99)\end{array}$ & $\begin{array}{c}1.07 \\
(0.89)\end{array}$ \\
\hline noinfo & $2.52^{* *}$ & $2.36^{*}$ & $2.44^{*}$ & $3.18^{* *}$ \\
\hline [1 if NOINFO] & $(1.28)$ & (1.24) & (1.29) & (1.45) \\
\hline usa $\times$ noinfo & $-3.60 * *$ & $-3.51^{* *}$ & $-3.53 * *$ & $-3.64 * *$ \\
\hline [interaction term] & $(1.51)$ & $(1.50)$ & $(1.51)$ & (1.60) \\
\hline own-income & & 0.02 & 0.02 & 0.01 \\
\hline [participant’s income from performance] & & $(0.02)$ & $(0.02)$ & $(0.02)$ \\
\hline own-luck & & $0.02 * *$ & $0.02^{*}$ & 0.02 \\
\hline [participant’s income from luck] & & $(0.01)$ & $(0.01)$ & $(0.01)$ \\
\hline other-total-income & & 0.00 & 0.00 & 0.01 \\
\hline [other participant's total income] & & $(0.01)$ & $(0.01)$ & $(0.01)$ \\
\hline hard & & & 0.21 & 0.12 \\
\hline [how hard you worked on the task] & & & $(0.14)$ & $(0.14)$ \\
\hline female & & & -1.21 & -0.41 \\
\hline [1 if female] & & & $(0.82)$ & $(0.84)$ \\
\hline age & & & $0.30^{*}$ & 0.23 \\
\hline [age of a participant] & & & $(0.17)$ & $(0.21)$ \\
\hline income & & & 0.16 & 0.00 \\
\hline [categorical income variable] & & & $(0.45)$ & $(0.46)$ \\
\hline proportion & & & 0.40 & 0.53 \\
\hline [proportion of income from work] & & & $(0.32)$ & $(0.33)$ \\
\hline family & & & 0.03 & 0.41 \\
\hline [importance of family] & & & $(0.39)$ & $(0.46)$ \\
\hline religion & & & 0.26 & 0.15 \\
\hline [importance of religion] & & & $(0.20)$ & $(0.26)$ \\
\hline leisure & & & 0.17 & 0.22 \\
\hline [importance of leisure time] & & & $(0.32)$ & (0.39) \\
\hline politics & & & -0.14 & -0.02 \\
\hline [political view] & & & $(0.28)$ & $(0.31)$ \\
\hline work & & & 0.23 & 0.19 \\
\hline [importance of work] & & & $(0.26)$ & $(0.26)$ \\
\hline luck & & & -0.29 & -0.14 \\
\hline [importance of luck] & & & $(0.26)$ & $(0.29)$ \\
\hline government & & & -0.2 & -0.21 \\
\hline [responsibilities of government] & & & $(0.19)$ & $(0.20)$ \\
\hline constant & $1.92^{* * *}$ & -0.13 & -9.01 & -8.52 \\
\hline & $(0.60)$ & $(1.87)$ & $(5.48)$ & $(6.77)$ \\
\hline Observations & 277 & 277 & 267 & 209 \\
\hline
\end{tabular}

